\title{
Use of Collagen, PTFE and PRF Membranes in Bone Reconstruction an Experimental and Histomorphometric Study
}

\author{
Ioana Irina Neculae ${ }^{1}$, Vlad Marian Anghelescu ${ }^{1}$, Sabina Andrada Zurac ${ }^{2}$, Octavian Marius Dinca ${ }^{1}$, \\ Cristian George Vladan ${ }^{1}$, Alexandru Bucur ${ }^{1}$
}

\section{Corresponding author:}

Ioana Irina Necolae, DMD DDS

Medical Department of Oro-Maxillo-

Facial Surgery

"Carol Davila" University of Medicine

and Pharmacy, Bucharest, Romania

E-mail: ioana_neculae84@yahoo.com
${ }^{1}$ Medical Department of Oro-Maxillo-Facial Surgery,

Carol Davila University of Medicine and Pharmacy, Bucharest, Romania

${ }^{2}$ Medical Department of Pathology, Carol Davila University of Medicine and Pharmacy, Bucharest, Romania

\section{ABSTRACT}

Bone regeneration techniques cannot be done without barrier membranes, even if horizontal or vertical ridge augmentation and socket ridge preservation is taken into consideration. This study presents a comparison between outcomes of bone regeneration, after producing standardized bone defects followed by covering them with membranes, on an animal experimental model. The study was conducted on 18 New Zeeland rabbits, by creating 2 defects in the left tibial bone of each rabbit: one standardized defect with a diameter of $4 \mathrm{~mm}$, and the second by creating 5 monocortical holes with a small round bur. The defects were augmented with bovine bone, beta-tricalcium phosphate and perioglass and they were covered with 3 types of membrane: collagen (12 defects - group A), PTFE membrane (12 defects - group B) and PRF membrane, made from the blood of the same rabbit (12 defects - group C). The animals were sacrificed after 6 months and analysed histomorphometrically. The new bone around graft particles has a thickness of $98.26 \mu \mathrm{m}$ for collagen membrane, $49.19 \mu \mathrm{m}$ for PTFE membrane and $63.98 \mu \mathrm{m}$ for PRF membrane. The density of osteoblasts and osteocytes has an average of 0.0012 for collagen membrane, 0.0009 for PTFE membrane and 0.0010 for PRF membrane. Regarding the collagen membrane, it is observed that when used the bone regeneration appears to have a higher density of osteoforming cells and a higher quantity of new bone

Key words: barrier membrane, bone regeneration, prf membrane, ptfe membrane, collagen membrane

\section{INTRODUCTION}

Reconstruction of bone defects of the upper and lower jaws is one the most challenging interests for oral and maxillofacial surgeons. (1) Detailed knowledge of the process which leads to such bone defects and awareness of several bone augmentation and bone regeneration techniques will improve the final results. Whether it involves horizontal or vertical ridge augmentation or socket ridge 
preservation, guided bone regeneration cannot be done without the use of barrier membranes. $(2,3)$ The barrier membranes allow a better integration of bone grafts on the receptor site, because of their role of maintaining a certain distance between the graft and the overlying soft tissues. $(4,5)$

This study presents o comparison between outcomes of bone regeneration, after producing standardized bone defects followed by covering them with membranes, on an animal experimental model. Advantages and disadvantages of resorbable and nonresorbable membranes have been discussed in detail for a very long time among surgeons. PRF (platelet rich fibrin), used by Choukroun in 2004, seems to bring a great benefit in GBR (guided bone regeneration) and GTR (guided tisular regeneration) techniques. (6) Yet, the short time of resorption of PRF seems to limit the use of these membranes, as the only membranes in bone regeneration. (7)

\section{MATERIALS AND METHODS}

This study involved 18 New Zeeland white rabbits ( 9 male and 9 female) with an average of 6 months of age and an average weight of $2.5 \mathrm{~kg}$, from "Cantacuzino" National Institute of Immunologic and Microbiologic Research, Bucharest. The animal study protocol was approved by the Ethical Committee of Animals from Bucharest. The animals were housed in special rooms (temperature $18{ }^{\circ} \mathrm{C}-24 \% \mathrm{C}$, humidity $50 \%-70 \%$, and a 12 hours light/dark cycle) and fed with a standard diet. The animals were randomly divided in three groups (Group A, Group B and Group C) depending on the used barrier membrane. The animals were sacrificed after 6 months using $200 \mathrm{mg} / \mathrm{ml}$ IV Phenobarbital. The bone defects were produced in the left tibial bone. The membranes used were: collagen membrane (Collprotect membrane - Botiss ${ }^{\circledR}$ ), d-PTFE membrane (Cytoplast TxT $200^{\circledR}$ ) and PRF membrane obtained from the blood of the experience animal. The animals were anesthetised with $10 \mathrm{mg} / \mathrm{kg}$ xylazine and $50 \mathrm{mg} / \mathrm{kg}$ ketamine.

\section{Platelet rich fibrin preparation method}

For our experiment $10 \mathrm{ml}$ of venous blood were obtained from the central vein of the ear and was centrifuged for 13 minutes at $3000 \mathrm{rpm}$. After the centrifugation, the blood was separated in three layers, the inferior layer (erythrocytic mass) and the top layer consisting of acellular platelet poor plasma were removed. The PRF clot in the middle was kept and compressed to obtain a membrane. (fig. 1) This membrane was used to cover 12 bone defects.

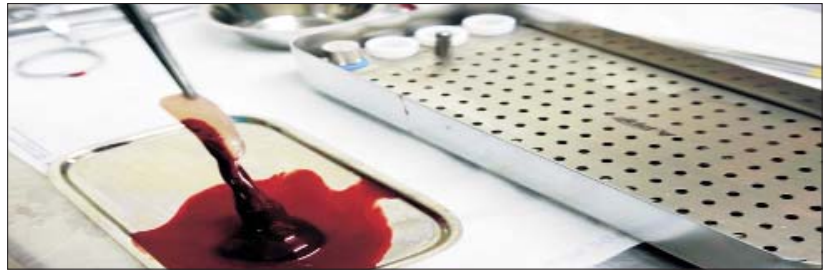

Figure 1 - PRF Membrane

\section{Surgical procedure}

After the general anaesthesia, the left tibial area was shaved and the skin was sterilized with povidone iodine solution. Using a $5 \mathrm{~cm}$ incision of skin, the subcutaneous and muscular tissues were dissected and the periosteum was removed from the bone. Two type of defects were created: one defect was a monocortical standardized defect made with a $4 \mathrm{~mm}$ diameter threphine burr under irrigation with saline solution, and the other defect, within a distance of $3 \mathrm{~mm}$, was made by drilling 5 monocortical holes with a small round burr. (fig. 2) The defects were augmented with three different materials: bovine bone (Biooss $^{\circledR}$ Geistlich Biomaterials, Switzerland, $0.25-1 \mathrm{~mm}$ ), beta-tri-calcium phosphate (40\%) with hydroxyapatite (60\%) (4 Bone $\mathrm{BCH}^{\circledR}$ - Mis, $0.5-1 \mathrm{~mm}$ ) and Perioglass $^{\circledR}$ (Novabone). (fig. 3) 12 defects were covered with collagen membranes (4 defects for each grafting material), 12 bone defects were covered with PTFE membrane and 12 defects were covered with PRF membranes from the same rabbit. After placement of the membranes suture was performed in three layers (periosteum, muscular tissue and skin). Postoperatively we administered intramuscular ketoprofen for 3 days.

We monitored the surgical wound for two weeks.

The animals were sacrificed after 6 months using Phenobarbital IV.

The left tibia was harvested and fixed with formaldehyde $10 \%$.

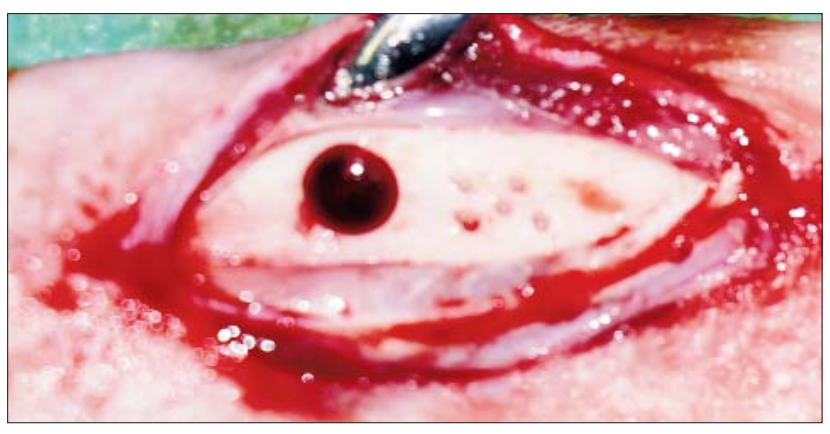

Figure 2 - The two types of bone defects 


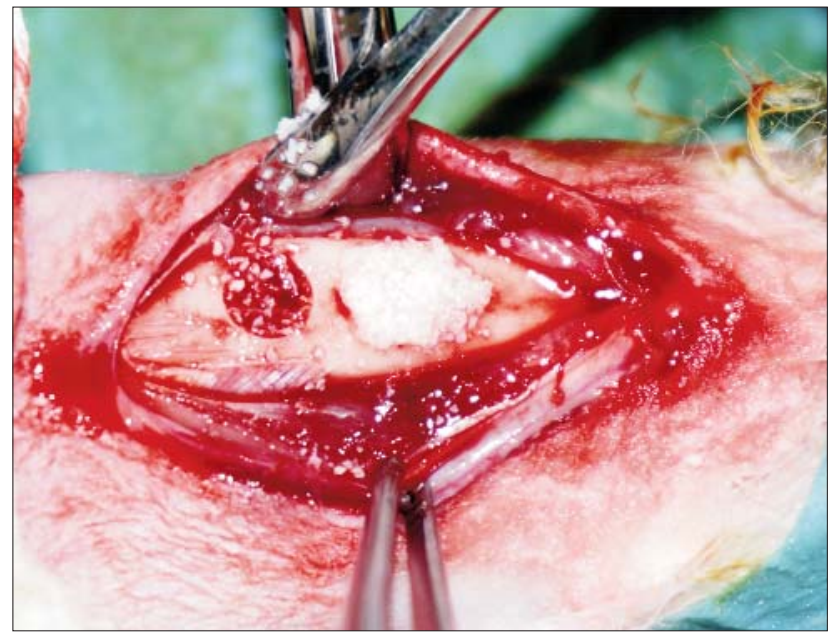

Figure 3 - The defects augmented with Biooss

\section{Histomorphometric evaluation}

After fixation of each specimen in formaldehyde $10 \%$, they were decalcified by using formic acid for 20 days, the solution being changed constantly. After decalcification, we harvested the areas of interest and continued with the histopatological evaluation. The specimens were introduced in paraffin blocks, then using a microtome several serial cross sections were made. The sections were fixed in haematoxylin-eosin and evaluated under the microscope (Olympus xc30 Optical Microscope). We evaluated new bone formation alongside the bone grafts, which was then measured and analysed. We also counted the number of osteoblasts and osteocytes from the areas of new bone (by use of Olympus CellSens Dimension). The results were compared depending on the barrier membranes. For statistical analysis we used SPSS program, version 24, from IMB.

\section{RESULTS AND DISCUSSION}

The rabbits were divided into three groups: group A, with collagen membranes, group $B$, with d-PTFE membranes and group $C$ with PRF membranes. The thickness of the new bone formed around the particles of the augmentation materials had an average of 98.26 $\mu \mathrm{m}$ for collagen membranes, $49.19 \mu \mathrm{m}$ for d-PTFE membranes and $63.98 \mu \mathrm{m}$ for PRF membranes. (table 1) The difference observed in non-resorbable membranes was a secondary phenomenon, by a small dehiscence which appeared in two rabbits of group B. This dehiscence permitted the infiltration of fibrous tissue, the membrane presenting with a degree of porosity. (fig. 4)

These differences are the same in regards to the cellular density (of osteoblasts and osteocytes) with an average of 0.0012 for collagen membranes, 0.0009 for d-PTFE membranes and an average of 0.0010 for PRF membranes. (table 2) The greater density of osteoblasts around the grafts particles showed a higher new bone apposition in that area. (fig. 5)

The differences between the two types of barrier membrane remained at a constant measure regardless of the type of grafting material that was used. A greater thickness of the newly formed bone was observed around the particles of bone graft and an increased cell

Table 1 - Statistical analysis of new bone thickness around particles of graft augmentation materials

\begin{tabular}{llcccc}
\hline & N & Minimum & Maximum & Mean & Std. Deviation \\
\hline The thickness of new bone for collagen membrane & 44 & 10.20 & 363.80 & 98.2664 & 85.53107 \\
\hline The thickness of new bone for d-PTFE membrane & 40 & 11.70 & 128.90 & 49.1930 & 29.07121 \\
The thickness of new bone for PRF membrane & 60 & 9.10 & 391.60 & 63.9883 & 55.55623 \\
\hline Valid N (listwise) & 40 & & & \\
\hline
\end{tabular}

Table 2 - Statistical analysis of density of osteoblasts and osteocytes form the new bone areas around particles of graft augmentation materials

\begin{tabular}{|c|c|c|c|c|c|}
\hline & $\mathbf{N}$ & Minimum & Maximum & Mean & Std. Deviation \\
\hline The density of cells for collagen membrane & 11 & .000814 & .002411 & .00126682 & .000485137 \\
\hline The density of cells for d-PTFE membrane & 13 & .000280 & .001787 & .00091092 & .000368236 \\
\hline The density of cells for PRF membrane & 15 & .000737 & .001432 & .00107593 & .000201207 \\
\hline Valid N (listwise) & 11 & & & & \\
\hline
\end{tabular}




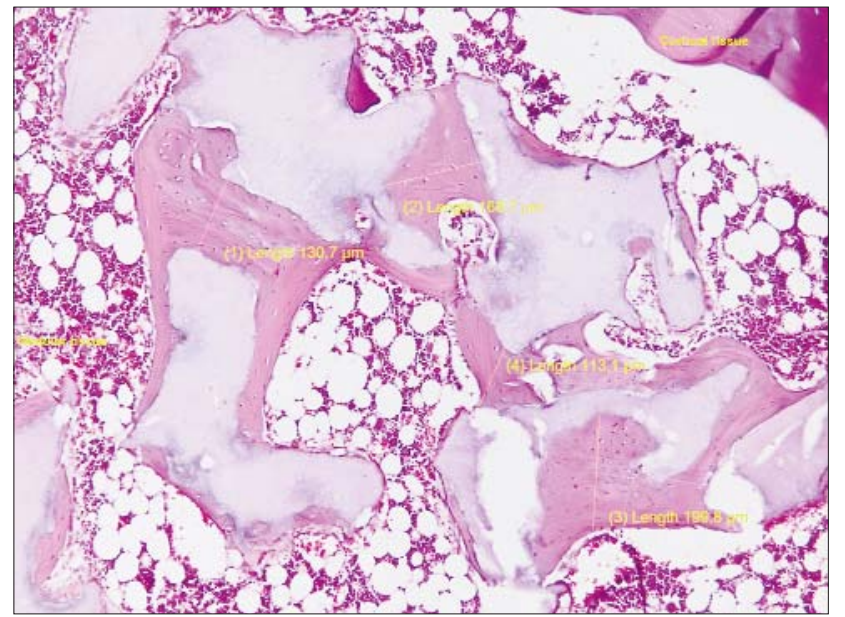

Figure 4 - Transversal section of rabbit tibia: area of augmentation with beta-tricalcium phosphate and collagen membrane. In the medullar bone tissue new bone around graft particles is shown

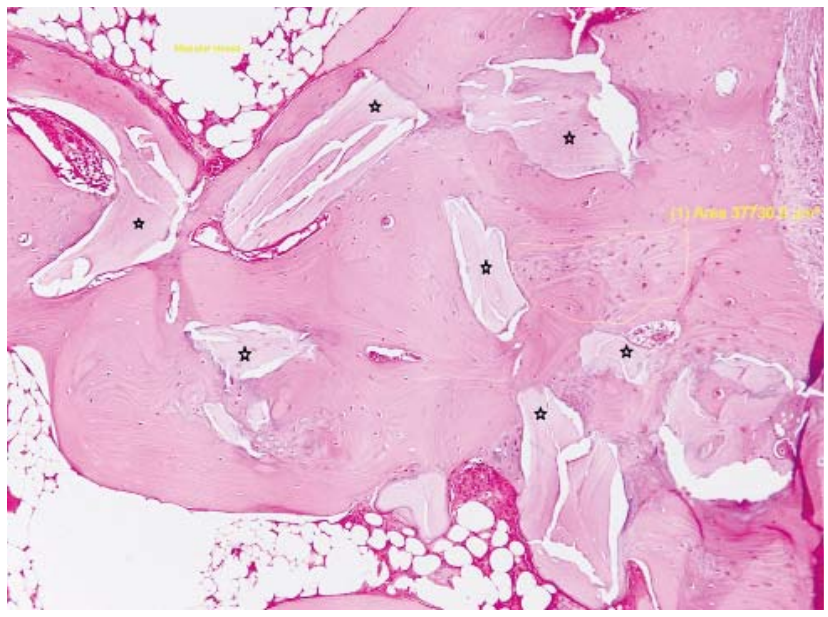

Figure 5 - Transversal section of rabbit tibia: area of Biooss augmentation and PRF membrane. In the cortical bone, it can be noted that the particles of Biooss (black stars) have integrated in an area of new bone. This area presents a high density of osteoblasts and osteocytes

density of osteoblasts for collagen membrane as compared to other types of membranes. Although three different types of bone augmentation materials were used, they did not influence the results.

A great variety of animal species are included in studies which concern bone regeneration in oral and maxillofacial surgery. (8) However, rats and rabbits are frequently used due to their easy handling, compared with other species, being also less expensive. (9) We used rabbits in our study because this species allows enough blood harvest to prepare a PRF membrane. The calvaria and tibia are the most used areas for bone regeneration studies. $(10,11)$

Barrier membranes are tested in a lot of experimental studies of bone regeneration and they are widely used in clinical therapy. (12-22) The placement of a barrier membrane promotes bone formation because it does not allow non-osteogenic soft tissue to infiltrate in the bone defect.

The d-PTFE membranes - polytetrafluoroethylene is a non-resorbable type of membrane, $100 \%$ dense with a $0.3 \mu \mathrm{m}$ pore size. A second surgery is needed in order to remove it. (fig. 6) (23-25)

Resorbable membranes are easier to use, but we cannot manage the time of their resorption and the effect that degradation has on the bone formation. (26, 27) The most important collagen membrane is BioGuide. It is a porcine collagen type I membrane, with a bilaminar structure, one dense layer and one porous layer. The dense layer has a polished surface which prevents the infiltration of epithelial cells in the bone defects, meanwhile, the porous surface enables the

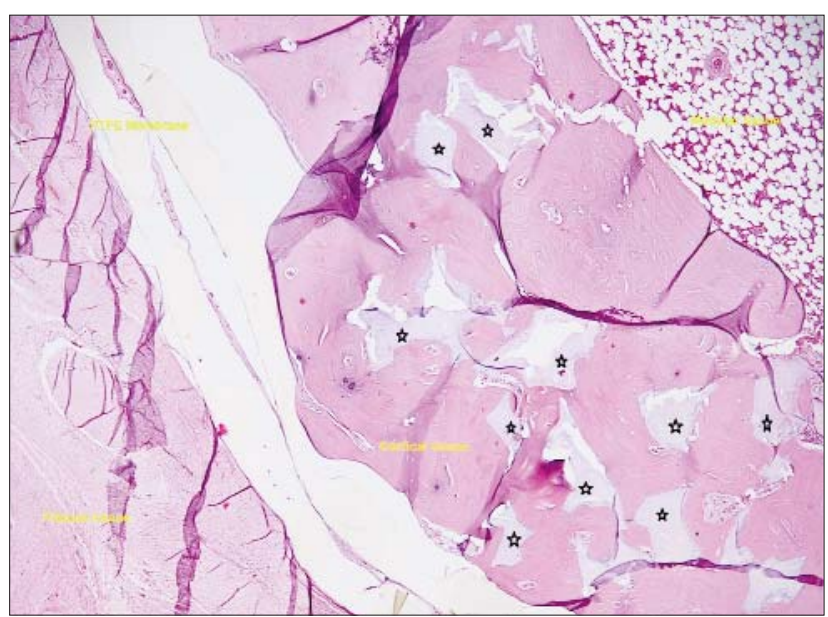

Figure 6 - Transversal section of rabbit tibia: area of beta-tricalcium phosphate and d-PTFE membrane. In the cortical bone there are particles of beta-tricalcium phosphate (black stars) and around them there is a high density of osteocytes

integration of the membrane in the tissues. (28)

PRF was developed by Choukroun in 2000, especially for usage in oral and maxillofacial surgery. Compared with PRP (platelet rich plasma), which is blood plasma that has been enriched with platelets, obtaining PRF is easier and it doesn't resorb as quickly. Growth factors from PRF are slowly released because of the fibrin matrix. (29) In a recent study regarding $P R F$, three different principal growth factors were found: TGFß-1, PDGF and VEGF, who remained in the PRF membranes for 7 days, because of the dense structure of fibrin and slow release into the tissues. (30) The structure of fibrin offers a bio-skeleton for cellular migration. $(31,32)$ 
In the present study it is important to mention that the membranes were used over bone defects created ad hoc. Bone regeneration is activated by the release of growth factors. The bone matrix is considered to be one of the richest source of growth factors, produced by osteoblasts and other cells. (33-35) The bone matrix is directly exposed to bone fractures, osteotomies, dental implant placement and other bone defects. Histologically, cellular activation is the expression of neoangiogenic stimulation, recruitment of osteoblasts and new bone formation. We can influence this process by using a barrier membrane, so we can concentrate the growth factors in the bone defect, and the bone defect is more quickly repaired. (36) Besides osteo-precursor cells, bone formation needs two things: blood supply and solid base for bone neo-apposition. (37) The pathway of bone regeneration in bone defects covered with membrane always starts from the bone walls towards the centre of the defect. (38)

\section{CONCLUSION}

In the present study it can be noted that bone regeneration differs depending on the type of barrier membranes used. There is an advantage of collagen membranes compared to non-resorbable d-PTFE membranes. The use of PRF membrane in bone augmentation techniques seems to bring a certain benefit. Coverage of bone defects with barrier membranes create a favourable environment for bone regeneration, because they create a space where osteogenic cells can migrate, and they prevent the non-osteogenic cells from the soft tissues to penetrate the bone defect. The membranes also represent a support for the soft tissues, preventing them from collapsing within the bone defect.

\section{REFERENCES}

1. Coradazzi LF, Garcia Jr IR, Manfrin TM. Evaluation of autogenous bone grafts, particulate or collected during osteotomy with implant burs: histologic and histomorphometric analysis in rabbits. Int $\mathrm{J}$ Oral Maxillofac Implants. 2007 Mar-Apr;22(2):201-7.

2. Giannoudis PV, Dinopoulos H, Tsiridis E. Bone substitutes: an update. Injury. 2005 Nov;36 Suppl 3:S20-7.

3. Costantino PD, Friedman CD. Synthetic bone graft substitutes Otolaryngol Clin North Am. 1994 Oct;27(5):1037-74.

4. Dahlin C, Sennerby L, Lekholm U, Linde A, Nyman S. Generation of new bone around titanium implants using a membrane technique: an experimental study in rabbits. Int J Oral Maxillofac Implants. 1989 Spring;4(1):19-25.

5. Buser D, Dula K, Belser U, Hirt HP, Berthold H. Localized ridge augmentation using guided bone regeneration. 1. Surgical procedure in the maxilla. Int J Periodontics Restorative Dent. 1993;13(1):29-45.

6. Choukroun J, Adda F, Schoeffler C, Vervelle A. Une opportunite' en paro-implantologie: le PRF. Implantodontie. 2001;42:55-62.

7. Choukroun J, Diss A, Simonpieri A, Girard MO, Schoeffler C, Dohan $S L$, et al. Platelet-rich fibrin (PRF): a second-generation platelet concentrate. Part IV: clinical effects on tissue healing. Oral Surg Oral Med Oral Pathol Oral Radiol Endod. 2006 Mar;101(3):e56-60.

8. Pripatnanont P, Nuntanaranont T, Vongvatcharanon S, Phurisat K. The primacy of platelet-rich fibrin on bone regeneration of various grafts in rabbit's calvarial defects. J Craniomaxillofac Surg. 2013 Dec;41(8): e191-200. doi: 10.1016/j.jcms.2013.01.018. Epub 2013 Feb 8.

9. Lee JW, Kim SG, Kim JY, Lee YC, Choi JY, Dragos R. Restoration of a peri-implant defect by platelet-rich fibrin. Oral Surg Oral Med Oral Pathol Oral Radiol. 2012 Apr;113(4):459-63. doi: 10.1016/..tripleo. 2011.03.043. Epub 2011 Jul 20.

10. Hokugo A, Sawada Y, Hokugo R, Iwamura H, Kobuchi M, Kambara T, et al. Controlled release of platelet growth factors enhances bone regeneration at rabbit calvaria. Oral Surg Oral Med Oral Pathol Oral Radiol Endod. 2007 Jul;104(1):44-8. Epub 2007 Mar 26.

11. Jiang ZQ, Liu HY, Zhang LP, Wu ZQ, Shang DZ. Repair of calvarial defects in rabbits with platelet-rich plasma as the scaffold for carrying bone marrow stromal cells. Oral Surg Oral Med Oral Pathol Oral Radiol. 2012 Mar;113(3):327-33. doi: 10.1016/j.tripleo.2011.03.026.

12. Dahlin C, Linde A, Gottlow J, Nyman S. Healing of bone defects by guided tissue regeneration. Plast Reconstr Surg. 1988 May;81(5): 672-6.

13. Dahlin C, Sennerby L, Lekholm, Linde A, Nyman S. Generation of new bone around titanium implants using a membrane technique: An experimental study in rabbits. Int J Oral Maxillofac Implants. 1989 Spring;4(1):19-25.

14. Dahlin C, Gottlow J, Linde A, Nyman S. Healing of maxillary and mandibular bone defects using a membrane technique. Scand J Plast Reconstr Hand Surg 1990;24:13-19.

15. Seibert J, Nyman S. Localized ridge augmentation in dogs: a pilot study using membranes and hydroxyapatite. J Periodontol. 1990 Mar;61(3):157-65.

16. Becker W, Becker B, Handlesman M, Celletti R, Ochsenbein C, Hardwick R, et al. Bone formation at dehisced dental implant sites treated with implant augmentation material: A pilot study in dogs. Int J Periodontics Restorative Dent. 1990;10(2):92-101.

17. Dahlin C, Alberius P, Linde A. Osteopromotion for cranioplasty. An experimental study in rats using a membrane technique. J Neurosurg. $1991 \mathrm{Mar} ; 74(3): 487-91$.

18. Warrer K, Gotfredsen K, Hjørting-Hansen E, Karring T. Guided tissue regeneration ensures osseointegration of dental implants placed into extraction sockets. An experimental study in monkeys. Clin Oral Implants Res. 1991 Oct-Dec;2(4):166-71.

19. Gotfredsen K, Warrer K, Hjørting-Hansen E, Karring T. Effect of membranes and porous hydroxyapatite on healing in bone defects around titanium dental implants. An experimental study in the monkey. Clin Oral Implants Res. 1991 Oct-Dec;2(4):172-8.

20. Gotfredsen K, Nimb L, Buser D, Hjørting-Hansen E. Evaluation of guided bone generation around implants placed into fresh extraction sockets: an experimental study in dogs. J Oral Maxillofac Surg. 1993 Aug:51(8):879-84; discussion 885-6.

21. Lekholm U, Becker W, Dahlin C, Becker B, Donath K, Morrison E. The role of early versus late removal of GTAM membranes on bone formation at oral implants placed into immediate extraction sockets. An experimental study in dogs. Clin Oral Implants Res. 1993 Sep;4(3): 121-9.

22. Linde A, Thorén C, Dahlin C, Sandberg E. Creation of new bone by an osteopromotive membrane technique: an experimental study in rats. J Oral Maxillofac Surg. 1993 Aug;51(8):892-7.

23. Bartee BK. The use of high-density polytetrafluoroethylene membrane to treat osseous defects: clinical reports. Implant Dent. 1995 Spring; 4(1):21-6.

24. Bartee BK, Carr JA. Evaluation of a high-density polytetrafluoroethylene membrane as a barrier material to facilitate guided bone regeneration in the rat mandible. J Oral Implantol. 1995;21(2):88-95.

25. Barber HD, Lignelli J, Smith BM, Bartee BK. Using a dense PTFE membrane without primary closure to achieve bone and tissue regeneration. J Oral Maxillofac Surg. 2007 Apr;65(4):748-52.

26. Wolf HF, Hassell TM, Aamodt GL. Periodontology: Color Atlas of Dental Hygiene. Stuttgart: Thieme Medical Publishers; 2006. p. 340.

27. Miller N, Penaud J, Foliguet B, Membre H, Ambrosini P, Plombas M. Resorption rates of 2 commercially available bioresorbable 
membranes. A histomorphometric study in a rabbit model. J Clin Periodontol. 1996 Dec;23(12):1051-9.

28. Taguchi Y, Amizuka N, Nakadate M, Ohnishi H, Fujii N, Oda K, et al. A histological evaluation for guided bone regeneration induced by a collagenous membrane. Biomaterials. 2005 Nov;26(31):615866.

29. Simonpieri A, Del Corso M, Sammartino G, Dohan Ehrenfest DM. The relevance of Choukroun's platelet-rich fibrin and metronidazole during complex maxillary rehabilitations using bone allograft. Part II: Implant surgery, prosthodontics, and survival. Implant Dent. 2009 Jun;18(3): 220-9. doi: 10.1097/ID.0b013e31819b5e3f.

30. Dohan Ehrenfest DM, de Peppo GM, Doglioli P, Sammartino G. Slow release of growth factors and thrombospondin- 1 in Choukroun's platelet-rich fibrin (PRF): a gold standard to achieve for all surgical platelet concentrates technologies. Growth Factors. 2009 Feb;27(1) 63-9. doi: 10.1080/08977190802636713.

31. Kang YH, Jeon SH, Park JY, Chung JH, Choung YH, Choung HW, et al. Platelet-rich fibrin is a bioscaffold and reservoir of growth factors for tissue regeneration. Tissue Eng Part A. 2011 Feb;17(3-4):349-59. doi: 10.1089/ten.TEA.2010.0327. Epub 2010 Dec 31.

32. Gassling V, Hedderich J, Açil Y, Purcz N, Wiltfang J, Douglas T.
Comparison of platelet rich fibrin and collagen as osteoblast-seeded scaffolds for bone tissue engineering applications. Clin Oral Implants Res. 2013 Mar;24(3):320-8. doi: 10.1111/j.1600-0501.2011.02333.x. Epub 2011 Nov 1.

33. Mohan S, Baylink DJ. Bone growth factors. Clin Orthop Relat Res. 1991 Feb;(263):30-48.

34. Mundy GR. Cytokines of bone. In: Mundy GR, Martin TJ (eds). Physiology an Pharmacology of Bone. Berlin, Heidelberg, New York: Springer; 1993. p. 85-214.

35. Centrella M, McCarthy TL, Canalis E. Growth factors and cytokines. In: Hall BK (ed): Bone, Vol 4: Bone Metabolism and Mineralization. Boca Raton, FL: CRC Press; 1992. p. 47-72.

36. Dahlin C, Hansson HA, Linde A. Expression of growth factors during healing of rat mandibular trephine lesions treated by the osteopromotive membrane technique. In: Dahlin C. Osteopromotion. University of Göteborg, Sweden: Thesis; 1993. p. 51-63.

37. Ham AW. Some histophysiological problems peculiar to calcified tissues. J Bone Joint Surg Am. 1952 Jul;24 A(3):701-28.

38. Pritchard JJ. General anatomy and histology of bone. In: Bourne GH (ed). The Biochemistry and Physiology of Bone. New York: Academic Press; 1956. p. 1-25. 